\title{
Studies on Flowering Pattern in Relation to Seed Filling and Seed Multiplication Rate in Groundnut (Arachis hypogaea L.)
}

\author{
N. Vinothini*, R. Vijayan and R. Umarani \\ Department of Seed Science and Technology, Tamil Nadu Agricultural University, \\ Coimbatore - 641003 Tamil Nadu, India \\ *Corresponding author
}

\section{A B S T R A C T}

\section{Keywords \\ Groundnut, Flowering pattern, Seed filling, Seed Multiplication rate, Days after sowing \\ Article Info \\ Accepted: \\ 24 August 2018 \\ Available Online: \\ 10 September 2018}

\begin{abstract}
The experiment was conducted in order to find out the effects of differential number of flowers plant ${ }^{-1}$ on pod and seed characteristics in the Department of Seed Science and Technology, Tamil Nadu Agricultural University, Coimbatore. In this experiment, the different number of flowers plant ${ }^{-1}$ was retained by manual pinching of late formed flowers. The number of flowers retained plant ${ }^{-1}$ varied from 11.08 (25 to 35 DAS), 36.63 (25 to 45 DAS), 89.33 (25 to 55 DAS), 125.04 (25 to 65 DAS), 169.32 (25 to 75 DAS), to 244.89 flowers (control plants). The yield attributing pod and seed characters viz., number of double seeded mature pods plant ${ }^{-1}$, weight of double seeded mature pods plant ${ }^{-1}$, number of mature seeds plant ${ }^{-1}$, weight of mature seeds plant ${ }^{-1}$ were highly influenced by the flowers retained between 25 to 55 days after sowing over control.
\end{abstract}

\section{Introduction}

Groundnut (Arachis hypogaea) is an important leguminous oilseed crop and generally called as poor man's nut. Groundnut seed contains 44 to $56 \%$ oil and 22 to $30 \%$ protein on dry seed basis and is a rich source of minerals $(\mathrm{P}$, $\mathrm{Ca}, \mathrm{mg}$ and $\mathrm{K}$ ) and vitamins (James et al., 2014).

Flowering and flowers assume an essential part in all seed crops, yield is dependent largely upon the fundamental reproductive units available. Flowering started 25 days after sowing and the day by day flower production expanded progressively with variations of high and low production. The main flowering time frame spread over around 40 days after which sporadic flowering were recorded. The flowering pattern was comparable for every one of the varieties studied and consisted of two peak periods, one occurring during the first 3 weeks of flowering and the second in after 70 days of flowering (Craufurd et al., 2000). Groundnut produces more number of flowers than the plant can sustain and develop into pods and < $15 \%$ to $20 \%$ of flowers produced into mature pods (Lim and Hamdan, 1984; Ramanatha and Murty, 1994).

For the most part, an extensive number of early formed flowers form into pods and flowers that appear 70 days after flowering do not form mature which result in low yield of 
mature pods (Knauft and Gorbet, 1989; Putnam et al., 1991; FAO, 1990). Groundnut flowers favor pod setting about 8 weeks to mature from the time of flowering and therefore, only the first 3 weeks of flowering may be considered to be useful (Bell et al., 1991; Awal and Ikeda, 2003). Fruiting efficiency of plants mainly depends on the pattern of flowering (number of flowers production up to 60 days), which is more important than total number of flowers per plant.

The early formed flowers (10 to 30) are more important components of early maturity in groundnut and a high proportion of the first 25 flowers developed into mature pods (Bailey and Bear, 1973). Likewise, the change of flowers to mature pods was the most important factors contributing to high pod yield (Songsri et al., 2009).

Indeterminate development habit in groundnut which results in overlapping of growth and development periods of the regenerative and vegetative organs prompting low fruiting efficiency. The latter is due to inter organ competition for nutrients and other metabolites. Subsequently, there is inappropriate partitioning of nutrients to the developing seeds. Most prominent limitation in the low yield is extended duration of flowering and variable seeds sizes. In this experiment, we hypothesised effect of flowering pattern in groundnut in relation to seed filling and seed multiplication rate.

\section{Materials and Methods}

Freshly harvested pods of groundnut variety TMV 7 collected from Oilseeds Research Station, Tindivanam, Tamil Nadu Agricultural University, served as source material for the study. A field experiment was conducted at Department of Seed Science and Technology, Tamil Nadu Agricultural University,
Coimbatore during Kharif (2015) with groundnut variety TMV 7 . The crop was maintained by following recommended package of practices (Crop Production Guide 2012 Dept. of Agriculture). The crop was observed for flower initiation and daily production. Flower initiation was observed on $25^{\text {th }}$ day after sowing (DAS). The flowers that emerged for the predetermined number of days were maintained and the flowers that emerged subsequently were manually removed (Fig. 1). The details of the treatments (flower retention) are as follows. $\mathrm{T}_{1}$ - Flowers produced from 25 to 35 days flowers retained, $\mathrm{T}_{2}$ - Flowers produced from 25 to 45 days flowers retained, $\mathrm{T}_{3}$ - Flowers produced from 25 to 55 days flowers retained, $\mathrm{T}_{4}$ - Flowers produced from 25 to 65 days flowers retained, $\mathrm{T}_{5}$ - Flowers produced from 25 to 75 days flowers retained, $\mathrm{T}_{6}$ - control (continuous flowering for entire crop duration). The following observations were recorded under field condition No. of flowers retained plant ${ }^{-1}$, No. of flowers removed plant ${ }^{-1}$, Pod set (\%), Total no. of pods plant ${ }^{-1}$, No. of double seeded pods plant $^{-1}$ (Mature and Immature), No. of single seeded pods plant $^{-1}$ (Mature and Immature), No. of ill filled pods plant ${ }^{-1}$, Total wt. of pods (g) plant ${ }^{-1}$, Wt. of double seeded pods (g) plant ${ }^{-1}$ (Mature and Immature), Wt. of single seeded pods $(\mathrm{g})$ plant $^{-1}$ (Mature and Immature), Wt. of ill filled pods (g) plant ${ }^{-1}$, No. of seeds plant ${ }^{-1}$ (Mature and Immature) and Wt. of seeds plant- ${ }^{1}$ (Mature and Immature). The data was collected from various experiments were analyzed statistically adopting the procedure described by Panse and Sukhatme (1985).

\section{Results and Discussion}

Field experiment on "studies on flowering pattern in groundnut in relation to seed filling and seed multiplication rate" was conducted during Kharif (2015) with groundnut variety TMV 7. In this experiment the desired number 
of flowers plant ${ }^{-1}$ was retained by manual pinching of late formed flowers. The number of flowers retained plant ${ }^{-1}$ varied from 11.08 (25 to 35 days) to 244.89 flowers (Control plants). Among the treatments maximum pod set per cent $(92.28 \%)$, were recorded in plants which were maintained with 11.08 flowers (25 to 35 days) (Table 1).

Among the treatments maximum number and weight of double seeded mature pods plant $^{-1}$ (16.57 and $20.12 \mathrm{~g}$ ) were recorded in plants which were maintained with 89.33 flowers (25 to 55 days). As the number of flowers retained plant $^{-1}$ increased further, these was reduction in number and weight of double seeded mature pods plant ${ }^{-1}$, to a level of $38.92 \%$ and 24.65 per cent in control

At the same time, the negative pod characteristics such as number and weight of double seeded immature pods plant ${ }^{-1}$, number and weight of single seeded mature pods plant ${ }^{-}$ 1 , number and weight of single seeded immature pods plant ${ }^{-1}$ and number and weight of ill filled pods plant ${ }^{-1}$ were recorded to $(8.31$, $5.08 \mathrm{~g}),(7.60,3.82 \mathrm{~g}),(3.14,1.71 \mathrm{~g})$ and $(11.10,1.31 \mathrm{~g})$ in control (Table 2 and 3$)$.

The maximum number of mature seeds plant $^{-1}$ (33.14) and weight of mature seeds plant $^{-1}$ $(16.99 \mathrm{~g})$ were recorded in plants which were maintained with 89.33 flowers in 25 to 55 days. As the number of flowers retained plant ${ }^{-}$ 1 increased further, these was reduction in number and weight of mature seeds plant ${ }^{-1}$, to a level of $40.06 \%$ and 47.79 per cent in control (Fig. 2).

Field experiment on "studies on flowering pattern in groundnut in relation to seed filling and seed multiplication rate" was conducted during Kharif (2015) with groundnut variety TMV 7. In this experiment the desired number of flowers plant ${ }^{-1}$ was retained by manual pinching of late formed flowers. The number of flowers retained plant $^{-1}$ varied from 11.08 (25 to 35 days) to 244.89 flowers (Control plants).

The maximum pod set per cent $(92.28 \%)$, were recorded in plants which were maintained with 11.08 flowers (25 to 35 days) (Fig. 3). The findings are in conformity with the results of Mondal et al., (2011b) observed that increases in leaf chlorophyll and nitrogen content of mungbean at the time of early growth development period which help in early formed flowers getting more available assimilates then later formed flowers. These advantages in producing high number of pod set thereby high yield. That is the reason, the higher rates of flower generation within 10 to 15 days after flowering revealed higher number of mature pod and seed yields. Further, earlier formed flowers had a higher pod set than the latter may be due to most of the sugar produced by leaf is utilized in filling the pods that occurs at proximal position of raceme (Spollen et al., 1986a).

Spollen et al., (1986b) reported assimilate translocation pattern in soybean, which early formed and later pods represented 70 and $30 \%$ of the translocated ${ }^{14} \mathrm{C}$, respectively. This information showed that grater part of the starch produced by leaf is used in filling the pods that set right on time at reproductive stage. Comparative phenomenon may have happened in the present experiment. Source constraint during seed filling appear to be moderately common as shown by starch and nitrogen levels in soybean leaves during seed filling (Egli and Bruening, 2003). Besides, several researchers (Saitoh et al., 1998) detailed that soybean yield under most field conditions is assumed to be source limited during the late reproductive period. Further, rachis diameter and radial length of xylem and phloem and vascular tissues diminished at the distal end compared to proximal one (Mondal et al., 2011b). 
Table.1 Effect of number of flowers retained plant ${ }^{-1}$ on pod set $(\%)$ in groundnut var. TMV7

\begin{tabular}{|c|c|c|c|}
\hline $\begin{array}{c}\text { Treatments (T) Retention } \\
\text { of flowers (Days) }\end{array}$ & $\begin{array}{l}\text { No. of flowers } \\
\text { retained plant }^{-1}\end{array}$ & $\begin{array}{l}\text { No. of flowers removed } \\
\text { plant }^{-1}\end{array}$ & Pod set $(\%)$ \\
\hline$T_{1}-25$ to 35 & 11.08 & 202.23 & $99.28(85.13)$ \\
\hline$T_{2}-25$ to 45 & 36.63 & 187.57 & $38.54(38.38)$ \\
\hline$T_{3}-25$ to 55 & 89.33 & 143.38 & $22.60(28.39)$ \\
\hline$T_{4}-25$ to 65 & 125.04 & 109.19 & 22.89 (28.58) \\
\hline$T_{5}-25$ to 75 & 169.32 & 63.55 & $20.08(26.62)$ \\
\hline $\mathrm{T}_{6}-$ Control & 244.89 & 0.00 & $16.57(24.02)$ \\
\hline Mean & 112.71 & 117.65 & $36.66(37.26)$ \\
\hline SEd & 7.2567 & 7.5093 & 1.7580 \\
\hline $\mathrm{CD}(\mathrm{P}=0.05)$ & $15.4675^{* *}$ & $16.0059 * *$ & $3.7472 * *$ \\
\hline
\end{tabular}

(Figures in parenthesis indicate arcsine values)

Table.2 Effect of number of flowers retained plant ${ }^{-1}$ on number of pods plant $^{-1}$ in Groundnut var. TMV7

\begin{tabular}{|c|c|c|c|c|c|c|}
\hline \multirow{2}{*}{$\begin{array}{c}\text { Treatments } \\
\text { (T) Retention } \\
\text { of flowers } \\
\text { (Days) }\end{array}$} & \multirow[t]{2}{*}{$\begin{array}{l}\text { Total no. of } \\
\text { pods plant }^{-1}\end{array}$} & \multicolumn{2}{|c|}{$\begin{array}{l}\text { No. of double seeded pods } \\
\text { plant }^{-1}\end{array}$} & \multicolumn{2}{|c|}{$\begin{array}{l}\text { No. of single seeded pods } \\
\text { plant }^{-1}\end{array}$} & \multirow{2}{*}{$\begin{array}{l}\text { No. of ill } \\
\text { filled pods } \\
\text { plant }^{-1}\end{array}$} \\
\hline & & Mature & Immature & Mature & Immature & \\
\hline$T_{1}-25$ to 35 & 11.01 & 11.01 & 0.00 & 0.00 & 0.00 & 0.00 \\
\hline $\mathrm{T}_{2}-25$ to 45 & 13.81 & 13.81 & 0.00 & 0.00 & 0.00 & 0.00 \\
\hline$T_{3}-25$ to 55 & 19.57 & 16.57 & 0.50 & 2.50 & 0.00 & 0.00 \\
\hline$T_{4}-25$ to 65 & 27.86 & 14.75 & 4.07 & 2.89 & 1.12 & 5.04 \\
\hline$T_{5}-25$ to 75 & 33.71 & 13.09 & 5.93 & 5.00 & 1.40 & 8.29 \\
\hline $\mathrm{T}_{6}-$ Control & 40.27 & 10.12 & 8.31 & 7.60 & 3.14 & 11.10 \\
\hline Mean & 24.37 & 13.22 & 3.13 & 3.00 & 0.94 & 4.07 \\
\hline SEd & 1.9694 & 0.5933 & 1.0542 & 0.8869 & 0.4590 & 1.9422 \\
\hline $\mathrm{CD}(\mathrm{P}=0.05)$ & $4.1978 * *$ & $1.2646 * *$ & $2.2469 * *$ & $1.8903 * *$ & $0.9783^{* *}$ & $4.1398 * *$ \\
\hline
\end{tabular}

Table.3 Effect of number of flowers retained plant ${ }^{-1}$ on weight of pods $(\mathrm{g})$ plant $^{-1}$ in Groundnut var. TMV7

\begin{tabular}{|c|c|c|c|c|c|c|}
\hline \multirow{2}{*}{$\begin{array}{l}\text { Treatments (T) } \\
\text { Retention of } \\
\text { flowers (Days) }\end{array}$} & \multirow{2}{*}{$\begin{array}{l}\text { Total wt. } \\
\text { of pods } \\
\text { (g) plant }{ }^{-1}\end{array}$} & \multicolumn{2}{|c|}{$\begin{array}{l}\text { Wt. of double seeded pods } \\
\text { (g) plant }{ }^{-1}\end{array}$} & \multicolumn{2}{|c|}{$\begin{array}{l}\text { Wt. of single seeded pods (g) } \\
\text { plant }^{-1}\end{array}$} & \multirow{2}{*}{$\begin{array}{l}\text { Wt. of ill } \\
\text { filled pods } \\
\text { (g) plant }{ }^{-1}\end{array}$} \\
\hline & & Mature & Immature & Mature & Immature & \\
\hline$T_{1}-25$ to 35 & 16.02 & 16.02 & 0.00 & 0.00 & 0.00 & 0.00 \\
\hline$T_{2}-25$ to 45 & 17.25 & 17.25 & 0.00 & 0.00 & 0.00 & 0.00 \\
\hline$T_{3}-25$ to 55 & 22.42 & 20.12 & 0.34 & 1.96 & 0.00 & 0.00 \\
\hline$T_{4}-25$ to 65 & 23.62 & 18.58 & 2.22 & 1.97 & 0.41 & 0.45 \\
\hline$T_{5}-25$ to 75 & 24.40 & 16.36 & 3.28 & 2.78 & 0.87 & 1.11 \\
\hline $\mathrm{T}_{6}-$ Control & 27.08 & 15.16 & 5.08 & 3.82 & 1.71 & 1.31 \\
\hline Mean & 21.80 & 17.25 & 1.82 & 1.75 & 0.50 & 0.48 \\
\hline SEd & 1.6341 & 1.1005 & 0.7195 & 0.5445 & 0.2219 & 0.3393 \\
\hline $\mathrm{CD}(\mathrm{P}=0.05)$ & $3.4831 * *$ & $2.3456 * *$ & $1.5336^{* *}$ & $1.1605 * *$ & $0.4729 * *$ & $0.7233^{* *}$ \\
\hline
\end{tabular}


Fig.1 Manual pinching of flowers

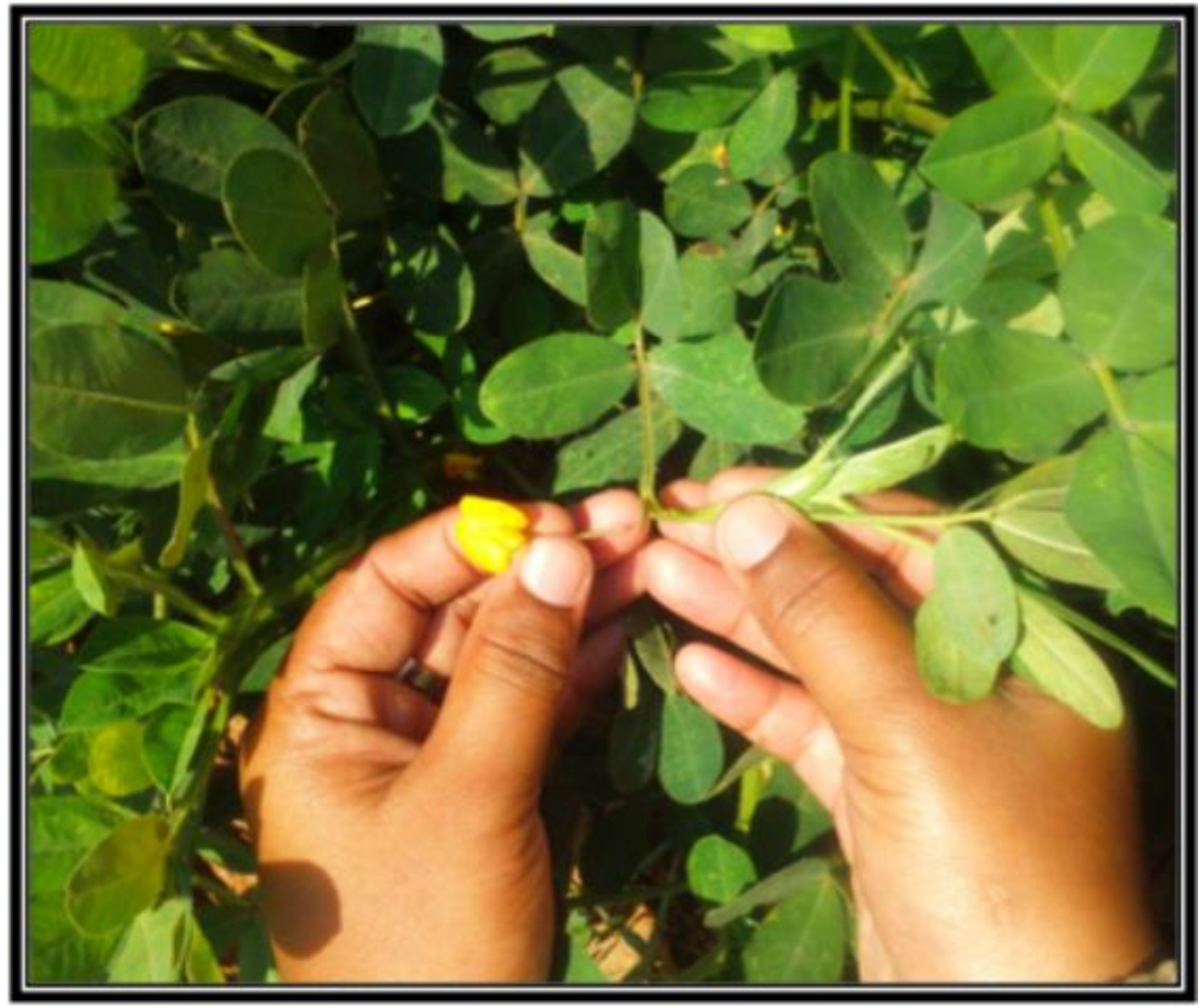

Fig. 2 . Effect of number of flowers retained plant ${ }^{-1}$ on number and weight seeds (g) in groundnut var. TMV7

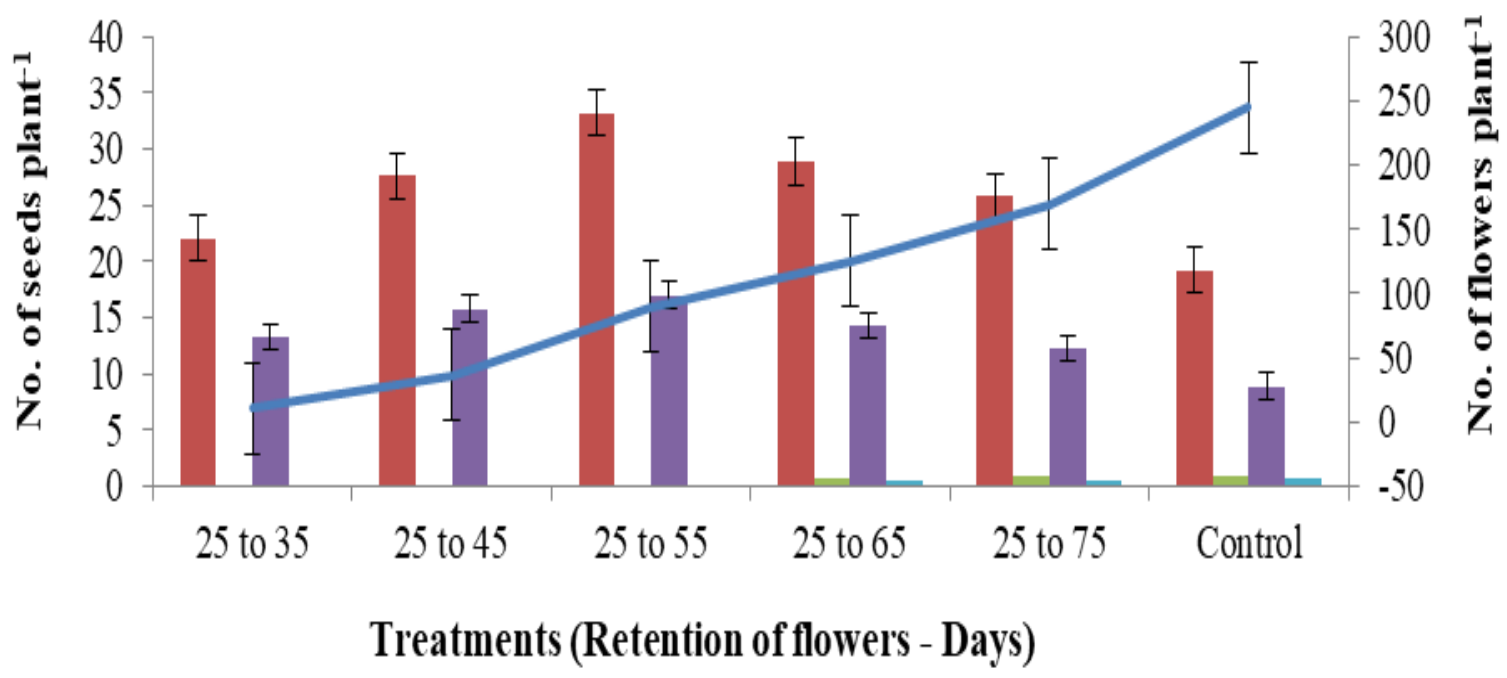

No. of mature seeds plant-1 $\quad$ No. of immature seeds plant- $1 \quad$ Wt. of mature seeds plant-1

Wt. of immature seeds plant-1 $\quad$ No. of flowers retained plant-1 
Fig.3 Effect of number of flowers retained plant ${ }^{-1}$ on pod set (\%) in groundnut var. TMV7

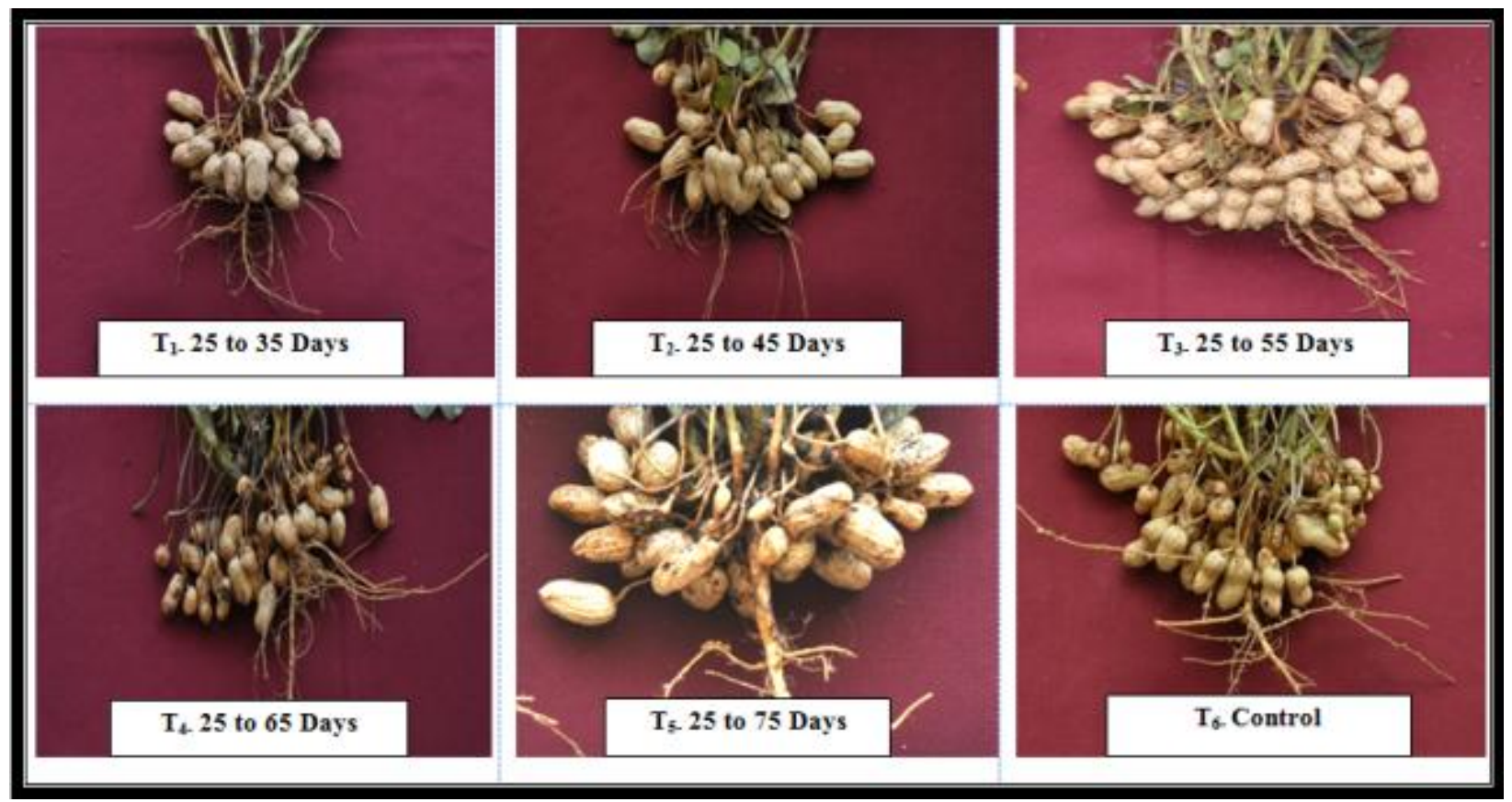

These outcomes recommended that phloem was ineffectively developed in the distal part of the raceme and consequently giving potentially insufficient amount of photosynthate to the later formed flowers, which may have caused more flower shedding at the distal end of the raceme. This further demonstrates irrespective of yield capacity, the mungbean genotype conceivably confer a vascular tissue constraint in the distal part of the rachis. Comparative outcomes were additionally found in soybean (Wiebold and Panciera, 1990), in lignosus bean (Bari and Prodhan, 2001) and in pigeonpea (Begum et al., 2007). Consequently, earlier formed flowers had a higher pod set than the latter. Saitoh et al., (1999) additionally observed that with increasing number of flowers per raceme, the rate of pod set per raceme diminished (Table 1).

Effect of number of flowers retained plant $^{-1}$ on number and weight of pods and seeds plant $^{-1}$. The findings are in similarity with the results of Yoshida et al., (1983) found that the magnitude and duration of flowering is more important since $>70 \%$ pods plant $^{-1}$ are formed from the initial 10 days of flowering in determinate type and 15 days in indeterminate kind of soybean. Comparable outcomes were documented by Mondal et al., (2011a), who examined flowering pattern in groundnut and mung bean and observed expanded number of flower generation within 15 to 20 days after flowering (DAF) in groundnut and 10 to 15 DAF in mung bean, likewise produced higher yield in groundnut and mung bean. However it is thoroughly thought out that the genotypes, which produced expanded number of flowers within shorter period of time especially at early development stages will permit them more time for assimilate accumulation and this accomplish more sink strength than the laterformed flowers (Biswas et al., 2005) (Table 2 and 3 ). The arresting of late formed flowers could have led to high sink potential and led to acceleration of assimilate translocation from source to sink there by enhanceing resulting in extended in seed filling period ( 25 to 55 days of flowers) when compared to control. 
Differential retention of flowers significantly influenced the number and weight of matured pods produced per plant. As the number of flowers retained decreased, there was an increase in the number of mature pods and its weight, number of mature seed and its weight. From the results it could be concluded that retention of flowers that were produced from 25 to 55 days were optimum for realizing enhanced source - sink relationship in groundnut.

\section{Acknowledgements}

Words are mere the verbal expression of one's thoughts and feelings. But there the words are poor substitute of expressing my deep sense of gratitude to my chairman, Dr. R. Vijayan and my member of the advisory committee, Dr. R. Umarani for his/her dexterous, meticulous and altruistic guidance, valuable suggestions and words of wisdom during my work. This research received no specific grant from any funding agency, commercial or not-for-profit sectors.

\section{References}

Awal, M.A., and Ikeda, T. 2003. Controlling canopy formation, flowering, and yield in field-grown stands of peanut (Arachis hypogaea L.) with ambient and regulated soil temperature. Field Crops Research 81: 121- 132.

Bailey, W.K., and Bear, J.E. 1973. Earliness of flower opening and potential for pod development in peanuts (Arachis hypogaea L.). Journal of American Peanut Research Education Association 5: 26-31.

Bari, S.M.A., and Prodhan, A.K.M.A. 2001. Anatomy of lignosus bean (Dipogon lignosus L.) IV. Rachis of inflorescence. Pakistan Journal of Biological Science 4: 1070-1074.
Begum, S., Islam, M.A. and Prodhan, A.K.M.A. 2007. Anatomy of rachis of the inflorescence in pigeon pea. International Journal of Botany 3: 8590.

Bell, M.J., Shorter, R. and Mayer, R. (1991) Cultivar and environmental effect on growth

and development of peanuts (Arachis hypogaea L). In Reproductive development. Field Crops Research 27: 35- 49.

Biswas, M.I., Hossain, M.A. and Fakir, M.S.A. 2005. Effect of defoliation at vegetative stage on dry mass production and yield in cowpea. Journal Bangladesh Agricultural University 3: 13- 20.

Craufurd, P.Q., Wheeler, T.R., Ellis, R.H., Summerfield, R.J. and Prasad, P.V.V. 2000. Escape and tolerance to high temperature at flowering in groundnut (Arachis hypogaea L.). Journal Agricultural Science 135: 371-378.

Crop Production Guide. (2012) Dept. of Agriculture Govt. of Tamil Nadu, Chennai-5.

Egli, D.B. and Bruening, W.P. (2003) Increasing sink size does not increase photosynthesis during seed filling in soybean. Journal Agronomy 19, 289298.

Food and Agricultural Organization (FAO). (1990) Soil Map of the world. Revised legend. 11.

James Seutra Kaba, F., Kumaga, K. and Kwadwo Ofori. 2014 Effect of flower production and time of flowering on pod yield of peanut (Arachis hypogaea L.). Journal Agricultural and Veterinary Science, 7: 44-49.

Knauft, D.A. and Gorbet, D.W. 1989. Genetic diversity among peanut cultivars. Crop Science 29: 1417- 1422.

Lim, E.S. and Hamdan, O. 1984. The reproductive characters of four varieties 
of groundnuts (Arachis hypogaea L.). Pertanica 7: 25- 31.

Mondal, M.M.A., Akter, M.B., Rahman, M.A. and Fakir, M.S.A. 2011b. Effect of foliar application of nitrogen on growth and yield in mungbean. Legume Research 34: 23- 30.

Mondal, M.M.A., Fakir, M.S.A., Juraimi, A.S., Hakim, M.A., Islam, M.M. and Shamsuddoha, A.T.M. 2011a. Effects of flowering behavior and pod maturity synchrony on yield of mungbean (Vigna radiata L.). Australian Journal Crop Science 5: 945- 953.

Panse, V.G. and Sukhatme, P.V. 1985. Statistical methods for agricultural workers, 97-164.

Putnam, D.H., Oplinger, E.S., Teynor, T.M., Oelke, E.A., Kelling, K.A. and Doll, J.D. 1991. Peanut: Alternative field crop manual: 56-58.

Ramanatha Rao, V. and Murty, U.R. 1994. Genotypic variations in dry matter production, chemical compositions and calcium efficiency ratio of groundnut grown on acid sands. J. Field Crop Research 14: 412-416.

Saitoh, K., Isobe, S. and Kuroda, T. 1998. Pod elongation and seed growth as influenced by nodal position on stem and raceme order in a determinate type of soybean cultivar. Japanese Journal Agricultural Science 67: 325- 328.

Saitoh, K., Isobe, S. and Kuroda, T. 1999. Intraraceme variation in the numbers of flowers and pod set in field grown soybean. Japanese Journal Agricultural Science 68: 397- 400.

Songsri, P., Jogloy, S., Holbrook, C.C., Vorasoot, N., Kesmala, T.C., Akkasaeng, C. and Patanothai, A. 2009. Association of root, specific leaf area and SPAD chlorophyll meter reading to water use efficiency of peanut under different available soil water. Agricultural Water Management: 790798.

Spollen, W.G., Wiebold, W.J. and Glenn, S. 1986a. Effect of altered intra raceme competition on carbon-14-labelled assimilate and abscisic acid in soybean. Crop Science 26: 1216-1229.

Spollen, W.G., Wiebold, W.J. and Glenn, S. 1986b. Intraraceme competition in field grown soybean. Journal Agronomy 78: 280-283.

Wiebold, J.W. and Panciera, M.T. 1990. Vasculature of soybean racemes with altered intra raceme competition. Crop Science 30: 1089- 1193.

Yoshida, K., Nomura and Gotoh, K. 1983. Significance of intra plant flowering date in soybean seed production. II. Number of flowers, podding efficiency, nodal distribution of pods and yield components among different flowering dates. Japanese Journal Agricultural Science 52: 567-573.

\section{How to cite this article:}

Vinothini, N., R. Vijayan and Umarani, R. 2018. Studies on Flowering Pattern in Relation to Seed Filling and Seed Multiplication Rate in Groundnut (Arachis hypogaea L.). Int.J.Curr.Microbiol.App.Sci. 7(09): 3321-3328. doi: https://doi.org/10.20546/ijcmas.2018.709.412 